\title{
PEMODELAN DAN PREDIKSI DAYA OUPUT PHOTOVOLTAIC SECARA REAL TIME BERBASIS MIKROKONTROLER
}

\author{
Eka Prasetyono $^{1}$, Ragil Wigas Wicaksana ${ }^{2}$, Novie A Windarko ${ }^{3}$, Moh. Zaenal Efendi ${ }^{4}$ \\ Prodi Teknik Elektro Industri, Depatermen Teknik Elektro, Politeknik Elektronika Negeri Surabaya \\ e-mail: ${ }^{1}$ eka@pens.ac.id, ${ }^{2}$ ragilwigas@yahoo.co.id, ${ }^{3}$ ayub@pens.ac.id, ${ }^{4}$ zen@ @ens.ac.id
}

\begin{abstract}
Abstrak - Energi listrik yang dihasilkan oleh photovoltaic (PV) sebagai sumber energi terbarukan sangat terpengaruh oleh kondisi lingkungan seperti besar kecilnya intensitas iradiasi sinar matahari, suhu, letak geografis dan orientasi kemiringan dari PV itu sendiri. Berapa daya yang seharusnya dihasilkan oleh PV untuk setiap saat dan dimana saja akan dibahas pada makalah ini. Pada makalah ini mengimplementasi clear sky solar irradiance, solar position dan PV temperatur model untuk memprediksi daya output yang seharusnya dihasilkan oleh PV. Model tersebut diimplemantasikan pada mikrokontroller ARM Cortex M4F STM32F407 yang merupakan mikrokontroller 32bit dan dilengkapi dengan DSP, sehingga prediksi daya output PV dapat dilakukan secara online dan real time. Untuk dapat memprediksi daya output PV secara online, setiap saat dan dimana saja berada, maka pada makalah ini mikrokontroler dilengkapi dengan sensor suhu dan input informasi geografis berupa lintang-bujur dan dilengkapi juga dengan memory card untuk data logger antara daya hasil prediksi dan daya hasil pengukurang dilapangan. Hasil yang telah diperoleh dari percobaan lapangan menunjukkan bahwa daya hasil pengukuran PV terhadap prediksi daya melalui model sangat mendekati dengan rata-rata error $4.72 \%$ dan penggunaan instruksi DSP pada mikrokontroler untuk perhitungan model waktu komputasinya 33.64\% lebih cepat dibandingkan tanpa instruksi DSP.
\end{abstract}

Kata Kunci : Photovoltaic, Prediksi daya secara real time dan Mikrokontroler.

\begin{abstract}
The electrical energy generated by the photovoltaic (PV) as a renewable energy source highly affected by environmental conditions such as intensity of sunlight irradiance, temperature, geographic location and tilt angle of PV itself. How much power should be generated by the PV for every times and anywhere will be discussed in this paper. This paper are implemented models of clear sky solar irradiance, solar position and PV temperature to predict the power output should be generated by PV. The model is implemented on the ARM Cortex M4F microcontroller STM32F407 which is a 32bit microcontroller and equipped with DSP, so the prediction of PV power output can be done online and in real time. To be able to predict the PV power output online, at any time and wherever they are, in this study microcontroller equipped with temperature sensors and input geographical information (latitude-longitude) and also equipped with a memory card for data logger between the predictions and field measurement. Results have been obtained by field experiments, measurements test for PV is very close to predictions with an average error $4.72 \%$ and computation time for all models by microcontroller with DSP instruction $33.64 \%$ faster compare to without DSP instruction.
\end{abstract}

Keywords : Photovoltaic, Real time power prediction and Microcontroller.

\section{PENDAHULUAN}

Solar PV merupakan penghasil sumber energi listrik terbarukan yang sangat potensial digunkan di Indonesia mengingat Indonesia merupakan negara yang dilintasi garis katulistiwa, sehingga enegi listrik yang dihasilkan dapat dalam jumlah yang besar. Berdasarkan data pengukuran pada 18 lokasi di Indonesia, potensi energi yang bisa didapatkan di Kawasan Barat Indonesia (KBI) sekitar 4,5 $\mathrm{kWh} / \mathrm{m}^{2} /$ hari dengan variasi bulanan sekitar 10\%; dan di Kawasan Timur Indonesia (KTI) sekitar $5,1 \mathrm{kWh} / \mathrm{m}^{2} /$ hari dengan variasi bulanan sekitar 9\% [16]. Dengan tingginya energi per satuan luas dan rendahnya variasi energi ini, pemanfaatan energi matahari untuk dikonversi menjadi energi listrik memiliki potensi yang sangat tinggi.

Melihat potensi energi yang dapat dihasilkan tersebut, maka dalam program pengembangan energi baru terbarukan Direktorat Jenderal Listrik dan Pemanfaatan Energi Departemen Energi dan Sumber Daya Mineral membentuk road map pengembangan PLTS untuk tahun 2005-2025 dengan kapasitas komulatif $0.8 \mathrm{GW}$ [17] seperti pada gambar 2. 


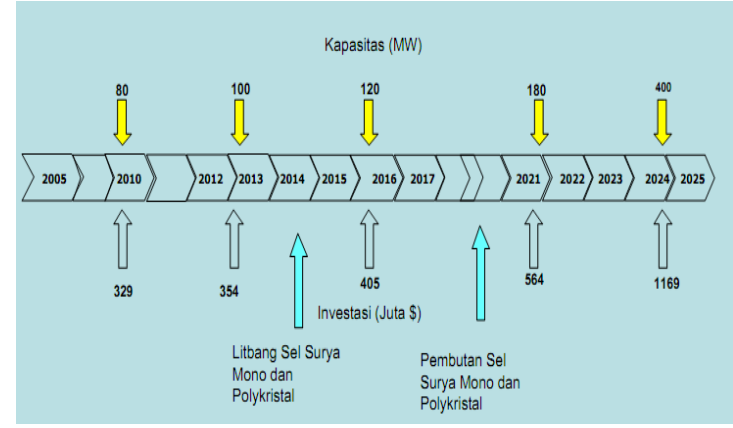

Gambar 1. Road map pengembangan PLTS Indonesia 2005-2025 [17].

Meskipun Indonesia memiliki yang tinggi untuk penerapan PLTS tetap harus diperhatikan bahwa PV dalam menghasilkan energi listrik baik digunakan untuk PLTS dalam skala besar maupun untuk skala kecil atau stand-alone seperti untuk lampu penerangan jalan semuanya sangat terpengaruh oleh faktor-faktor lingkungan seperti intensitas iradiasi sinar matahari, suhu, letak geografis dan orientasi kemiringan dari PV itu sendiri [1-2]. Para peneliti telah banyak mengembangkan cara untuk mendapatkan daya maksimal dari PV dengan metode MPPT mulai dari metode yang sederhana sampai menggunakan kecerdasan buatan. Pada beberapa penelitian dilaporkan bahwa MPPT dengan kecerdasan buatan mampu bekerja dengan baik walaupun kondisi permukaan PV tertutup sebagian [3-6].

Penelitian ini bertujuan membantu memprediksi besarnya daya listrik yang seharusnya dihasilkan oleh PV, sehingga pengguna PV akan dapat mengevaluasi apakah PV yang terpasang sudah tepat atau belum. Prediksi daya output PV ini dapat dipasang secara online dimana saja berada dan sekaligus dilengkapi dengan data logger untuk dapat mambandingkan daya prediksi dengan daya PV yang terukur dilapangan. Lebih jauh, diharapkan hasil prediksi daya output PV bisa digunakan untuk mengevaluasi kinerja MPPT.

\section{TINJAUAN PUSTAKA}

Besarnya instensitas sinar matahari pada permukaan bumi ditentukan oleh posisi matahari di langit terhadap bumi[8,9]. Posisi matahari dilangit terhadap bumi dimanapun kita berada sesuai dengan letak geografis lintang dan bujur dapat dihitung dengan persamaan zenith. Zenith dinyatakan dalam satuan derajat, zenith bernilai negatif pada pagi hari, bernilai positif untuk sore hari dan bernilai nol pada saat tengah hari. Untuk nilai zenith kurang dari $-90^{\circ}$ diartikan matahari belum terbit dan bila nilainya lebih dari $90^{\circ}$ diartikan matahari sudah terbenam. Ilustrasi zenith dan posisi matahari terhadap permukaan bumi dapat dilihat pada gambar 2 .

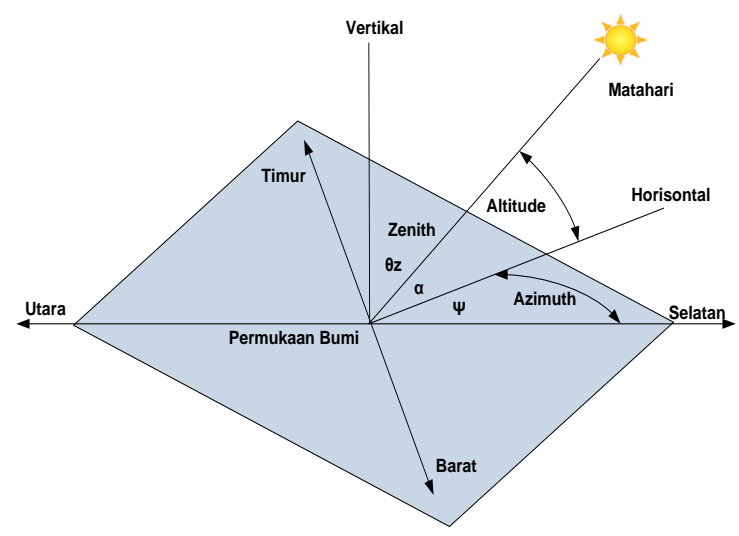

Gambar 2. Zenith dan sistem koordinatnya pada bumi.

Sudut zenith untuk setiap saat terhadap bumi pada suatu titik dengan letak geografis lintangbujur dapat dihitung dengan persamaan 1 [8-11].

$\cos (\theta z)=\cos (\varphi-\beta) \cos \delta \cos \omega+\sin (\varphi-$ $\beta) \sin \delta$

$\varphi$ merupakan nilai lintang (latitude) secara geografis dimana PV dipasang, $\beta$ merupakan sudut kemiringan PV (tilt angle), $\delta$ merupakan sudut deklinasi matahari, sudut ini selalu bergeser sedikit demi sedikit sepanjang tahun mengikuti pola rotasi bumi mengelilingi matahari[8,11], sudut deklinasi ini dapat dihitung melalui persamaan 2. Sedangkan $\omega$ merupakan sudut jam (hour angle), nilai sudut jam ini selalu berubah sesuai dengan perubahan waktu lokal atau jam dimana PV tersebut dipasang, waktu lokal ini ditentukan oleh letak bujur (longitude) secara geografis.

$$
\delta=23.45^{\circ} \sin \left(360^{\circ} \frac{284+n}{365}\right)
$$

sudut deklinasi $\delta$ merupakan fungsi yang dipengaruhi oleh hari ke- $n$ dalam setahun, dimana nilai $n$ antar 1 sampai 365 , nilai 1untuk tanggal 1 Januari dan nilai 365 untuk tanggal 31 Desember. Sedangkan untuk tahun kabisat 
dengan bulan februari 29 hari, maka diabaikan sehingga tanggal 31 Desember tetap hari yang ke 365. Sudut deklinasi matahari terhadap bumi dapat diilustrasikan seperti pada gambar 3 .

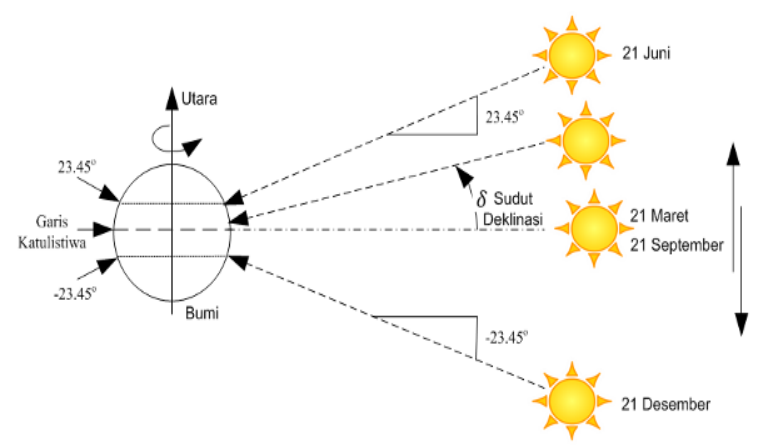

Gambar 3. Sudut deklinasi posisi matahari terhadap bumi.

Untuk $\omega$ (hour angle) sangat erat kaitannya dengan waktu lokal, sehingga kesalahan pada nilai hour angel akan menyebabkan kesalahan nilai zenith yang signifikan. Nilai hour angel akan bernilai nol pada saat tengah hari, bernilai negatif pada pagi hari dan bernilai positif pada sore hari. Nilai hour angle setaiap jamnya akan bertambah $15^{\circ}$. Untuk dapat menghitung hour angle dengan tepat dapat dihitung melaluai persamaan 3, hour angel dinyatakan dalam satuan derajat[8].

$$
\omega=(\text { Solar time }-12) \times 15^{\circ}
$$

Solar time pada persamaan 3 meruapakan waktu yang lokal sesuai dengan letak geografis dan sudah terdapat faktor koreksi terhadap standar waktu meridian. Solar time [8] dapat dicari dengan persamaan 4 berikut.

$$
\text { Solar time }=\text { waktu lokal }+\left(\frac{(\text { LSTM-Longitude }) x 4^{\prime}+E o T}{60}\right)
$$

Local Standard Time Meridian ( LSTM) merupakan waktu standar meridian yang dapat dihitung melalui persamaan 5. Sedangkan nilai 4' (empat menit) mreupakan faktor pengali yang diperoleh dari rotasi bumi setiap $1^{\circ}$ (satu derajat) memerlukan waktu empat menit. Untuk equation time (EoT) merupakan faktor koreksi waktu sesuai rotasi bumi terhadap matahari. ( LSTM) dapat dihitung dengan persamaan 5 berikut ini.

$$
L S T M=15^{\circ} \times \Delta T_{G M T}
$$

$\Delta T_{G M T}$ pada persamaan 5 adalah selisih waktu secara time zone atau bisa kita kenal dengan istilah zona waktu, sedangkan nilai $15^{\circ}$ dipapatkan dari setiap selisih satu jam zona waktu besarnya adalah $15^{\circ}$. untuk (EoT) yang merupakan faktor koreksi waktu dapat dihitung dengan persamaan 6 berikut ini :

$$
E o T=9.87 \sin (2 x)-7.53 \cos (x)-1.5 \sin (x)
$$

Dimana nilai $x$ pada persamaan 6 dapat diperolah dari persamaan 7 berikut ini

$$
x=\frac{360}{365} n-81
$$

Untuk nilai $n$ merupakan hari ke- $n$ dalam setahun, dimana nilai $n$ antar 1 sampai 365 , nilai 1untuk tanggal 1 Januari dan nilai 365 untuk tanggal 31 Desember.

Setelah mengetahui posisi matahari terhadap bumi atau tehadap PV yang terpasang, langkah selanjutnya adalah menghitung besarnya intensitas iradiasi sinar matahari untuk setiap saat sesuai dengan besar kecilnya hour angle. Besarnya radiasi sinar matahri $I_{o}$ dapat dihitung dengan persamaan 8 berikut ini $[8,13]$.

$$
I_{o}=I_{S C}\left(1+0.033 \cos \frac{2 \pi}{365} n\right) \cos \theta_{z}
$$

Pada persamaan $8 I_{s c}$ merupakan konstanta besarnya iradiasi sinar matahari $1.367 \mathrm{~kW} / \mathrm{m}^{2}$ dengan toleransi $1 \%$ [13-15], sedangkan $n$ merupakan hari ke- $n$ dalam setahun, dimana nilai $n$ antar 1 sampai 365, nilai 1untuk tanggal 1 Januari dan nilai 365 untuk tanggal 31 Desember. $\theta_{z}$ merupakan sudut Zenith yang dapat dihitung melalui persamaan 1. Besarnya intensitas iradiasi sinar matahari secara global (GHI) yang mencapai permukaan bumi dapat dihitung dengan clear sky model seperti Daneshyar-Paltridge-Proctor model and Meinel Model $[8,13]$. Berikut ini adalah persamaan untuk menghitung besarnya $G H I$.

$G H I=D N I x \cos \theta_{z}+$ Diffuse

(9)

$$
\text { Diffuse }=14.29+21.04\left(\frac{2 \pi}{2-\frac{\left(\theta_{Z} \pi\right)}{180}}\right)
$$

$D N I=I_{o} x 0.7^{A M^{\wedge} 0.678}$ 


$$
A M=\frac{1}{\cos \theta_{z}}
$$

Besarnya GHI diperoleh dari besarnya intensitas iradiasi secara langsung ( DNI ) ditambah dengan pantulan iradiasi sinar matahari (Diffuse). Sedangkan $\theta_{z}$ merunpan sudut Zenith.

Setelah mengetahui besarnya intensitas iradiasi sinar matahari secara global langkah selanjunya adalah menghitung besanya daya yang dapat dihasilkan oleh PV sesuai dengan besarnmya GHI dan suhu PV saat itu. Besarnya daya yang dapat dihasilkan oleh PV $\left(P_{P V}\right)$ yang dipengaruhi oleh besar kecilanya iradiasi sinar matahari dan panas dinginnya suhu PV [7,12] dapat dihitung dengan persamaan 13 berikut ini.

$$
P_{P V}=P_{P V, S T C} f_{P V} f_{\text {temp }}\left(\frac{G H I}{I_{T, S T C}}\right)
$$

Dimana $P_{P V, S T C}$ adalah daya nominal PV sesuai dengan rating daya pada name plate, $f_{P V}$ adalah faktor penurunan daya PV dengan nilai antara 0.85 sampai 1.1 . Sedangkan $f_{\text {temp }}$ adalah faktor penurunan daya akibat panas dinginnya suhu pada PV yang dapat dihitung melalui persamaan 14. GHI besarnya iradiasi sinar matahari yang sedang terjadi dan dapat dihitung melaui persamaan 9. $I_{T, S T C}$ adalah besarnya iradiasi sinar matahari pada saat pengetesan di pabrik, besarnya $I_{T, S T C}$ dapat dilihat pada name plate atau kataog dari PV yang digunakan.

$$
f_{\text {temp }}=\left[1+\alpha_{P}\left(T_{c}-T_{C, S T C}\right)\right]
$$

Untuk $\alpha_{p}$ merupakan koefisien suhu PV $\left(\% /{ }^{\circ} \mathrm{C}\right), T_{c}$ merupakan suhu cell PV $\left({ }^{\circ} \mathrm{C}\right)$ dan $T_{c, S T C}$ adalah suhu PV pada kondisi standart pengetesan dengan nilai $25^{\circ} \mathrm{C}$. Sedangkan untuk suhu cell PV $\left(T_{c}\right)$ dapat diperkirakan melalui persamaan 15 berikut ini.

$$
T_{c}=T_{a}+I_{T}\left(\frac{T_{c, N O C T}-T_{a, N O C T}}{I_{T, N O C T}}\right)\left(1-\frac{\eta_{c}}{\tau \alpha}\right)
$$

Dimana $T_{a}$ merupakan besarnya suhu lingkungan $\left({ }^{\circ} \mathrm{C}\right), T_{c, N O C T}$ adalah suhu normal PV dapat diopersaikan $\left({ }^{\circ} \mathrm{C}\right)$. Sedangkan $T_{a, \text { NOCT }}$ suhu lingkungan dalam kondisi normal sebesar $\left(20^{\circ} \mathrm{C}\right)$ dan $I_{T, N O C T}$ besarnya iradiasi sinar matahri dalam kondisi normal sebesar 0.8 $\mathrm{kW} / \mathrm{m}^{2} . \eta_{c}$ merupakan besarnya efisiensi PV, $\tau \alpha$ merupakan kemampuan daya serap iradiasi matahari dari PV dengan nilai minimal $90 \%$. Nilai-nilai parameter ini dapat ditemukan di name plate atau katalog PV yang digunakan.

\section{METODOLOGI}

PV yang akan prediksi dan diukur dayanya bersifat umum, sehingga diperlukan data parameter PV sebagai data input. Data parameter PV yang dimaksud adalah rating daya, koefisien suhu, standar radisi sinar matahari saat diuji pada pembutan PV dan lain-lainnya sesuai kebutuhan untuk perhitungan melalui model. Data ini dapat diperoleh secara lengkap pada name plate PV atau pada katalog PV yang digunakan. Kesalahan pada input data parameter PV akan menyebabkan kesalahan prediksi daya PV, karena model bekerja sesuai dengan data parameter PV yang diberikan.

Blok diagram sistem prediksi daya PV pada penelitian ini dapat dilihat pada gambar 4. Pada gambar tersebut dapat dilihat pada dasarnya sistem terdiri dari dua bagian, yaitu bagian prediksi daya dan bagian monitoring atau pengukuran daya dan data logging. Kedua bagian tersebut pada dasarnya merupakan bagian terpisah karena kedua sistem tersebut dapat berjalan atau bekerja sendiri-sendiri tanpa saling mempengaruhi, akan tepapi pada penelitian ini karena mikrokontroler yang digunakan memiliki kemampuan komputasi yang cepat, maka kedua sistem tersebut dikontrol oleh satu buah mikrokontroler STM32F407.

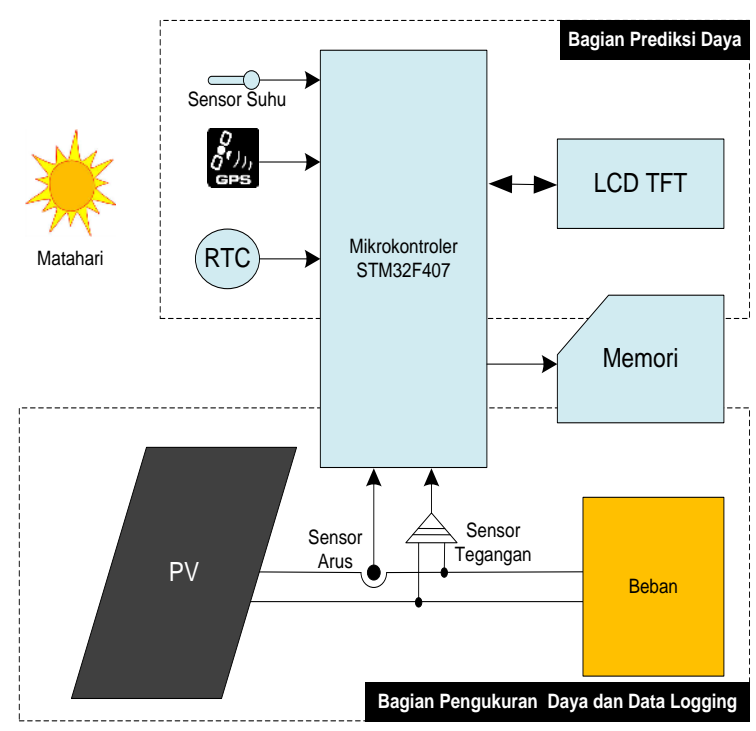

Gambar 4. Blok diagram system 
Untuk mengetahui panas dinginnya suhu PV maka dipasang sensor suhu berupa thermocouple. Sensor suhu ini tidak dapat mengkur suhu Cell PV secara langsung akan tetapi suhu yang dapat diukur adalah suhu lingkungan, selanjutnya suhu cell PV dapat dihitung melalui model pada persamaan 15. Sedadngkan untuk mengetahui letak lintang-bujur secara geografis dapat ditambahkan GPS, dengan adanya GPS ini posisi lintang-bujur dimanapun berada dapat terdeteksi secara otomatis. Bila tidak memiliki GPS data geografis lintang bujur dapat dimasukkan secar manual melaui LCD TFT ataupun ditanamkan melalui program.

Untuk kebutuhan prediksi daya PV sensor berikutnya yang wajib ada adalah sistem pewaktu yang bisa menunjukan waktu berupa tanggal, bulan dan tahun serta jam menit detik. Sistem pewaktu ini biasa dikenal dengan istilah real time clock (RTC). Untuk kebutuhan prediksi daya sensor-sensor yang digunakan telah cukup, selanjutnya data dari sensor akan diolah oleh mikrokontroler untuk menentukan besar kecilnya prediksi daya yang dapat diproduksi oleh PV.

Sedangkan untuk kebutuhan monitoring atau pengukuran kinerja PV hanya diperlukan tambahan sensor arus dan sensor tegangan serta beban yang nilai dayanya sesuai dengan rating maksimal daya PV. Untuk mendapatkan beban sesuai dengan daya PV dapat dipilih bebab resistif. Nilai resistansi beban dapat dihitung dengan hukum ohm seperti pada persamaan 16, dimana untuk nilai $V_{m p p}$ dan $I_{m p p}$ dapat dilihat pada name plate $\mathrm{PV}$ atau katalog $\mathrm{PV}$ yang digunkan. Jika beban PV berupa converter yang sudah dilengkapi dengan MPPT, maka beban sudah dianggap maksimal karena adanya MPPT.

$$
R_{m p p}=\frac{V_{m p p}}{I_{m p p}}
$$

Sebagaimana digambarkan pada blok diagram bahwa sistem ini terbagi dalam dua bagian, maka flowchart dari sistem ini juga dapat dibagi dalam dua diagram. Gambar 5 merupakan flowchart sistem prediksi daya secara real time. Sedangkan untuk gambar 6 merupakan flowchart pengukuran kinerja PV secara real time.

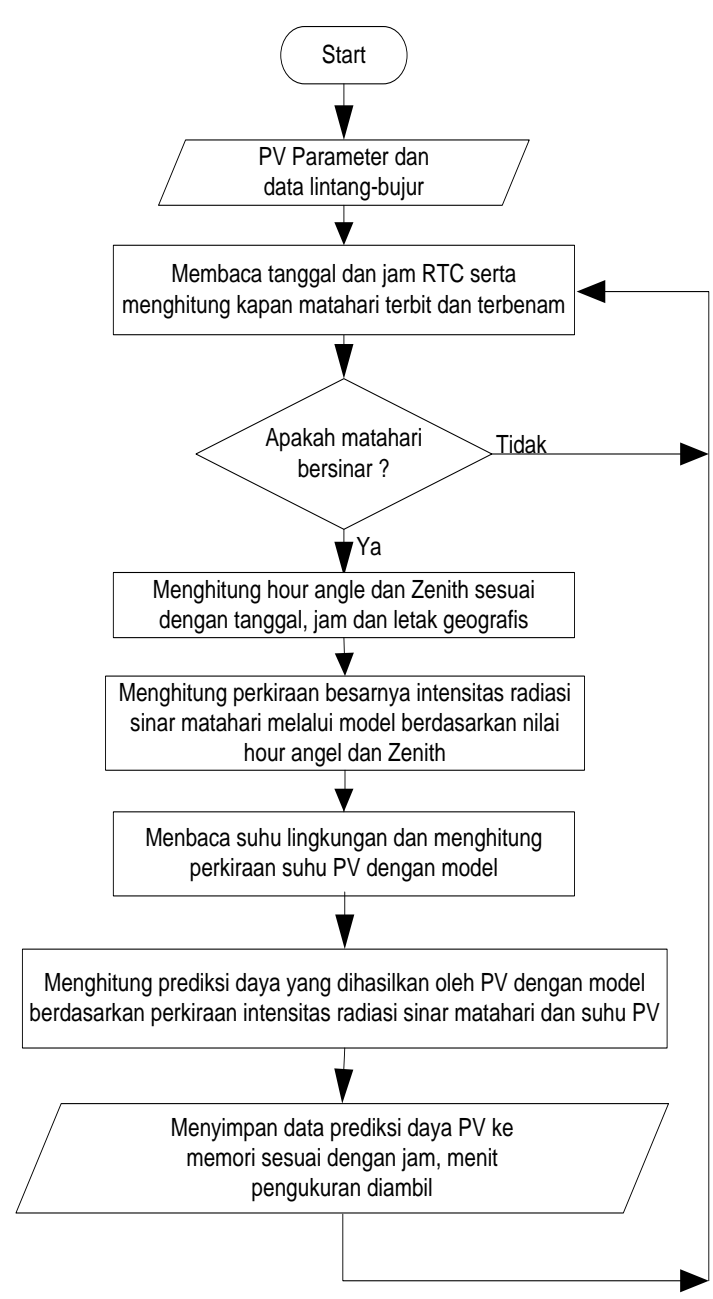

Gambar 5. Flowchart sistem prediksi daya secara real time.

Dalam implemetasi model untuk prediksi daya PV pada mikrokontrler akan menggunakan instruksi DSP dari ARM fast math. Instruksi ini memiliki fitur lebih ringan dalam komputasi sehingga waktu yang diperlukan dalam perhitungan bisa lebih singkat. Intruksi DSP fast math yang akan digunakan adalah $a r m \_s i n \_f 32$ dan $a r m \_c o s \_f 32$, tidak menggunakan standart sin dan cos dari library math.h. 


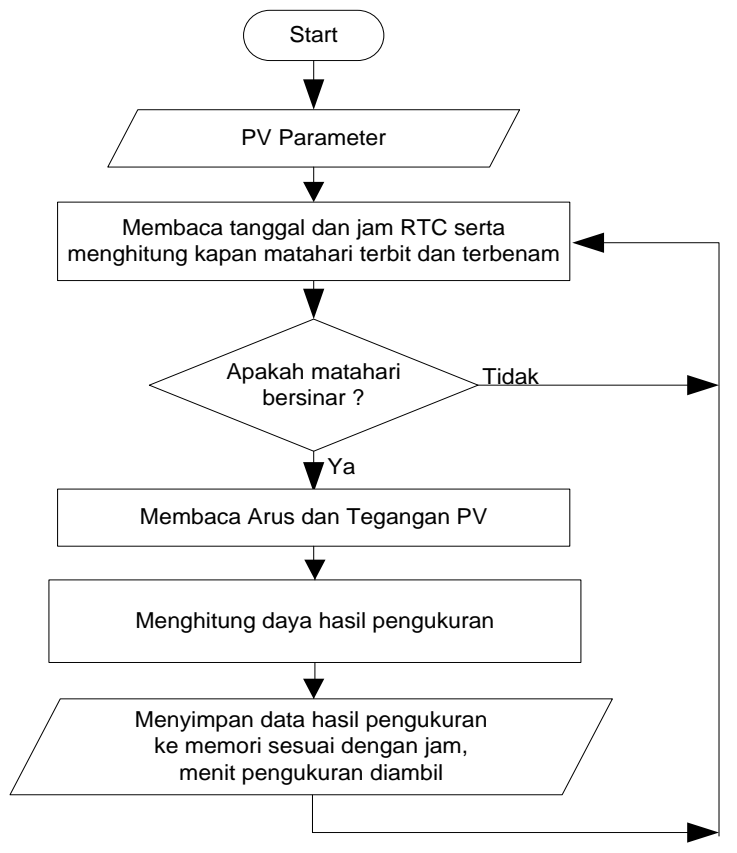

Gambar 6. Flowchart monitoring daya secara real time.

\section{HASIL DAN PEMBAHASAN}

Pada paper ini PV yang menjadi acuan untuk prediksi daya dan pengukuran kinerja PV dilakukan tehadap PV 100WP dimana data parameter PV 100WP dapat dilihat pada tabel 1 berikut ini.

Tabel 1. Parameter PV 100WP.

\begin{tabular}{|c|c|c|}
\hline Model & \multicolumn{2}{|l|}{ SL100CE-18M } \\
\hline Power & \multirow{2}{*}{\multicolumn{2}{|c|}{$\begin{array}{l}10 \text { Years of } 90 \% \text { Output Power, } 25 \\
\text { Years of } 85 \% \text { Output Power }\end{array}$}} \\
\hline Warranty & & \\
\hline \multicolumn{3}{|c|}{ ELECTRICAL DATA AT STC } \\
\hline \multicolumn{2}{|c|}{ Maximum Power (Pmax) } & 100 \\
\hline \multicolumn{2}{|c|}{ Voltage at Maximum Power (Vmpp) } & 17.49 \\
\hline \multicolumn{2}{|c|}{ Current at Maximum Power (Impp) } & 5.71 \\
\hline \multicolumn{2}{|c|}{ Open Circuit Voltage (Voc) } & 21.67 \\
\hline \multicolumn{2}{|c|}{ Short Circuit Current (Isc) } & 6.11 \\
\hline \multicolumn{2}{|c|}{ Panel Efficiency } & 12.02 \\
\hline \multicolumn{2}{|c|}{ Power Tolerance(Positive) } & \\
\hline \multicolumn{2}{|c|}{ Power Tolerance(Negative) } & -5 \\
\hline \multicolumn{3}{|c|}{$\begin{array}{l}\text { Standard Test Conditions (STC): air mass AM } 1.5 \text {, } \\
\text { irradiance } 1000 \mathrm{~W} / \mathrm{m}^{2} \text {, cell temperature } 25^{\circ} \mathrm{C}\end{array}$} \\
\hline \multicolumn{3}{|c|}{ Thermal Ratings } \\
\hline \multicolumn{2}{|c|}{ Operating Temperature Range } & $-45 \sim 85{ }^{\circ} \mathrm{C}$ \\
\hline \multicolumn{2}{|c|}{ Temperature Coefficient of Pmax } & $-0.47 \% /{ }^{\circ} \mathrm{C}$ \\
\hline \multicolumn{2}{|c|}{ Temperature Coefficient of Voc } & $-0.38 \% /{ }^{\circ} \mathrm{C}$ \\
\hline \multicolumn{2}{|c|}{ Temperature Coefficient of Isc } & $0.04 /{ }^{\circ} \mathrm{C}$ \\
\hline
\end{tabular}

Pengambilan data pada paper ini di lakukan dilingkungan Politeknik Elektronika Negeri Surabaya (PENS) dengan letak geografis pada -
$7.276623^{0}$ lintang selatan, $112.7949201^{0}$ bujur timur. Pengambilan data dilakukan pada bulan Oktober 2014. Gambar 7 merupakan prototype alat yang telah dibuat untuk prediksi daya dan pengukuran kinerja PV.

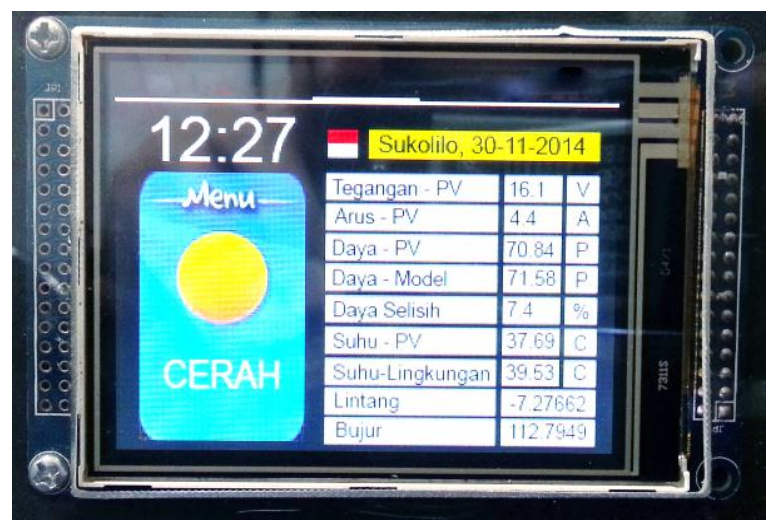

Gambar 7. Prototipe alat yang telah dibuat.

Pada gambar 8 merupakan proses pengambilan data dilapangan secara real time yang dilakukan di atas lantai 3 gedung PENS, pengambilan data ini dilakukan di lantai 3 dengan tujuan menghindari adanya bayangbayang gedung ataupun pepohonan yang menghalangi sinar matahari ke permukaan PV pada pagi hari dan sore hari.

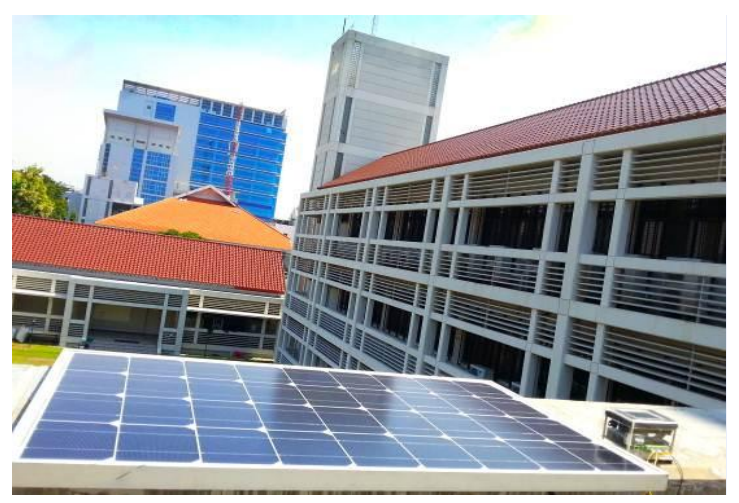

Gambar 8. Pengujian lapangan.

Sesuai dengan prencanaan bahwa perhitungan model untuk prediksi daya akan dilakukan denga instruksi DSP fast math FPU software, maka dapat dilihat pada table 2 bahwa dengan instruksi fast math memiliki waktu pengerjaan yang lebih $33.64 \%$ cepat dibandingkan tanpa instruksi DSP, sehingga proses perhitungan dapat dilakukan lebih real time. 
Tabel 2. Perbandingan waktu komputasi model untuk prediksi daya dengan instruksi DSP dan tanpa DSP pada mikrokontroler

\begin{tabular}{|c|c|}
\hline & $\begin{array}{c}\text { Waktu } \\
\text { komputasi } \\
\text { (mikro second) }\end{array}$ \\
\hline Tanpa DSP & 235.81 \\
\hline Dengan DSP & 156.48 \\
\hline Selisih waktu komputasi & 79.33 \\
\hline $\begin{array}{c}\text { Selisih kecepatan komputasi } \\
(\%)\end{array}$ & 33.64 \\
\hline
\end{tabular}

Sesuai dengan persamaan 15 , bahwa suhu cell PV dapat diperoleh dari suhu lingkungan yang diformulasikan dalam persamaan tersebut. Hasil pengukuran suhu lingkungan terhadap suhu cell PV dapat dilihat pada gambar 9, dari gambar tersebut terlihat jelas ketika pagi hari dan sore hari suhu cell PV hampir sama dengan suhu lingkungan, tetapi untuk siang hari suhu cell $\mathrm{PV}$ akan selalu lebih besar dari suhu lingkungan. Untuk proses selanjutnya pada setiap prediksi daya dan pengukuran kinerja PV selalu akan dilakukan perhitungan untuk mendapatkan suhu cell PV terlebih dahulu, sehingga akan dapat diketahu besarnya suhu cell PV dan daya yang dihasilkan oleh PV.

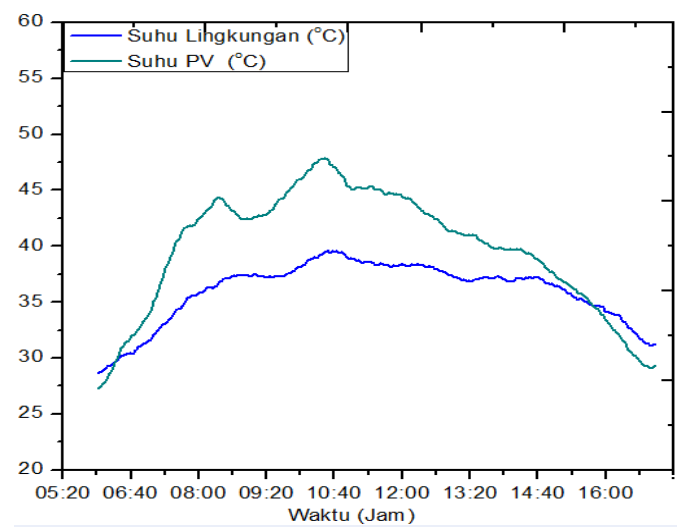

Gambar 9. Pengaruh suhu lingkungan terhadap suhu PV.

Hasil prediksi daya dan pengukuran kinerja PV 100WP dapat dilihat pada gambar 10 . Dimana pada grafik tersebut tampak terdapat selisih daya antara prediksi dengan model dan hasil pengukuran. Selisih daya ini dapat di bagi dalam tiga kelompok waktu, yaitu pagi hari sebelum jam 08.40, antara jam 08.40 sampai jam 14.00 dan sore hari setelah jam 14.00.

Untuk jam 08.40 sampai 14.00 selisih daya antara prediksi dengan hasil pengukuran tidaklah terlalu jauh yaitu dengan selisih daya rata-rata 3.23 Watt atau sebesar $4.52 \%$. Pagi hari daya yang dihasilkan PV berada dibawah prediksi daya, dengan error mencapai $27.96 \%$. Sedangkan untuk sore hari daya yang dihasilkan PV juga berada dibawah prediksi daya, dengan error mencapai $17.12 \%$. Hal ini terjadi kemungkinan karena posisi matahri yang rendah dan sensitivitas PV yang kurang baik.

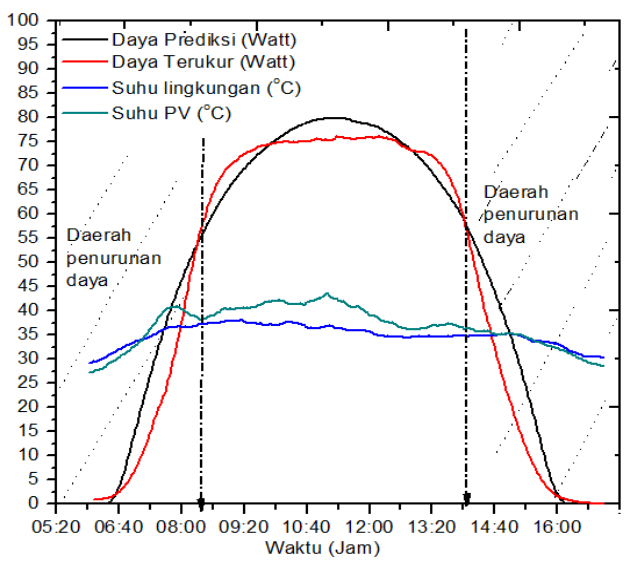

Gambar 10. Hasil prediksi daya dan pengukuran daya PV 100WP dengan posisi mendatar.

Setelah melakukan validasi prediksi daya PV 100WP dengan posisi mendatar, pengujian selanjutnya dilakukan terhadap PV 100WP yang dipasang dengan kemiringan $23^{\circ}$. sudut $23^{\circ}$ dipilih karena sudut deklinasi matahari maksimal sebesar $23.45^{\circ}$. Gambar 11 menunjukkan prediksi daya dan daya hasil pengukuran.

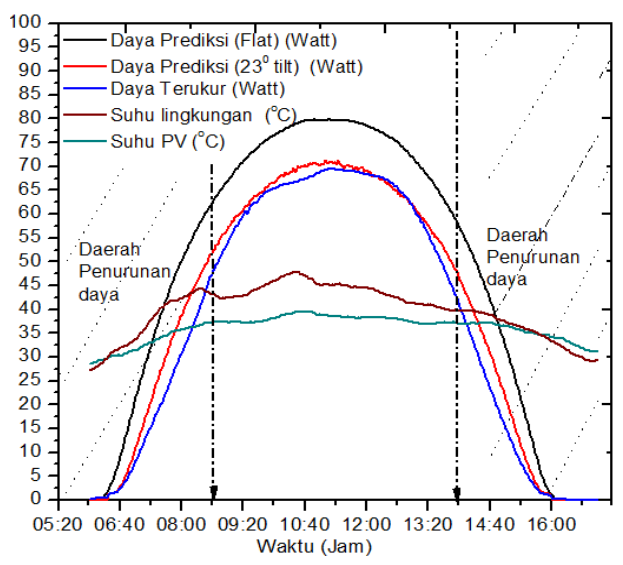

Gambar 11. Hasil prediksi daya dan pengukuran daya PV 100WP dengan posisi kemiringan $23^{\circ}$ ke utara. 
Untuk bahan pembanding dilakukan pula pengujian terhadap PV 100WP yang dipasang dengan kemiringan $7^{\circ}$, sudut $7^{\circ}$ dipilih karena lokasi PV yang dipasang berada di Surabaya tepatnya dikampus PENS dengan letak geografis lintang $-7.276623^{\circ}$ berada diselatan katuslistiwa. Gambar 12 menunjukkan prediksi daya dan daya hasil pengukuran dengan dengan kemiringan PV $7^{\circ}$.

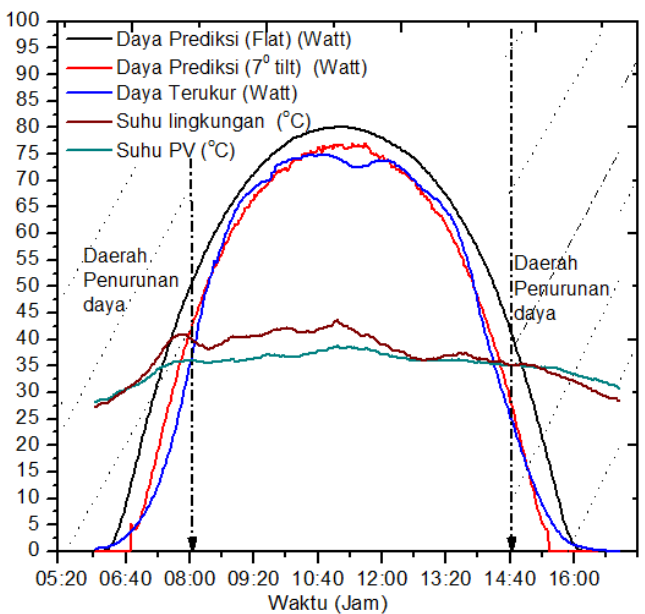

Gambar 12. Hasil prediksi daya dan pengukuran daya PV 100WP dengan posisi kemiringan $7^{0}$ ke utara.

Pada gambar 11 dan gambar 12 dapat dilihat bahwa PV dengan kemiringan $7^{\circ}$ dan $23^{\circ}$ baik secara prediksi maupun pengukuran di lapangan besarnya energi listrik yang dihasikan oleh PV dayanya lebih kecil dibandingkan dengan PV posisi mendatar. Hal ini disebabkan karena posisi matahari pada saat itu sedang berada di selatan katulistiwa dengan nilai sudut deklinasi $(\delta)$ sekitar 7 derajat, sehingga dengan kemiringan $\mathrm{PV} 7^{\circ}$ dan $23^{\circ}$ menyebabkan daya PV tidak maksimal.

Dari semua percobaan maka pengamatan daya ini dapat di bagi dalam tiga kelompok waktu, yaitu pagi hari sebelum jam 08.40, antara jam 08.40 sampai jam 14.00 dan sore hari setelah jam 14.40. Daya rata-rata baik secara pengukuran maupun prediksi dapat dilihat pada tabel 3 berikut ini.
Tabel 3. Daya rata-rata untuk prediksi daya dan hasil pengukuran.

\begin{tabular}{|c|c|c|c|c|}
\hline \multicolumn{2}{|c|}{ Daya rata-rata (Watt) } & $\begin{array}{c}\text { PV } \\
(\text { datar })\end{array}$ & $\begin{array}{c}\text { PV } \\
\left(7^{0}\right)\end{array}$ & $\begin{array}{c}\text { PV } \\
\left(23^{0}\right)\end{array}$ \\
\hline $\begin{array}{c}\text { Sebelum } \\
\text { Jam 08.40 }\end{array}$ & Prediksi & 27.40 & 23.07 & 22.61 \\
\cline { 2 - 5 } Pengukuran & 21.08 & 16.51 & 11.90 \\
\hline Jam 08.40 & Prediksi & 73.41 & 68.83 & 63.84 \\
-14.00 & Pengukuran & 73.48 & 70.03 & 61.51 \\
\hline $\begin{array}{c}\text { Setelah } \\
\text { jam 14.00 }\end{array}$ & Prediksi & 21.19 & 14.27 & 13.79 \\
\cline { 2 - 5 } & Pengukuran & 17.93 & 15.12 & 10.21 \\
\hline
\end{tabular}

Ketapatan prediksi daya dan terhadap hasil pengukuran dapat dilihat pada tabel 4. Dalam hal ini pengukuran dilakukan terhadap PV yang sama selama satu hari penuh.

Tabel 4. Rata-rata Error prediksi daya dan terhadap hasil pengukuran.

\begin{tabular}{|c|c|c|c|c|}
\hline Error & $\begin{array}{c}\text { PV } \\
(\text { datar })\end{array}$ & $\begin{array}{c}\text { PV } \\
\left(7^{0}\right)\end{array}$ & $\begin{array}{c}\text { PV } \\
\left(23^{0}\right)\end{array}$ & $\begin{array}{c}\text { Rata- } \\
\text { rata }\end{array}$ \\
\hline $\begin{array}{c}\text { Sebelum } \\
\text { Jam 08.40 }\end{array}$ & $27.96 \%$ & $26.68 \%$ & $35.05 \%$ & $29.89 \%$ \\
\hline $\begin{array}{c}\text { Jam 08.40 } \\
-14.00\end{array}$ & $4.52 \%$ & $4.29 \%$ & $5.35 \%$ & $4.72 \%$ \\
\hline $\begin{array}{c}\text { Setelah } \\
\text { jam } 14.00\end{array}$ & $17.12 \%$ & $11.09 \%$ & $18.01 \%$ & $15.40 \%$ \\
\hline
\end{tabular}

PV dapat menghasilkan energi listrik dengan daya yang sesuai dengan prediksi daya terjadi antara jam 08.40 sampai jam 14.00 dengan error rata-rata $4.72 \%$. Sedangkan untuk pagi hari dan sore hari PV tidak dapat menghasilkan daya susuai model relaif error diatas $11 \%$, namun yang perlu perlu diperhatikan untuk waktu pagi hari maupun sore hari prediksi daya yang dihasilkan PV juga sangalah kecil jauh dibawah rating daya $\mathrm{PV}$.

Pada hasil percobaan menunjukkan untuk PV dengan posisi mendatar dapat menghasilkan daya paling besar, kemudian untuk daya paling kecil terjadi pada PV dengan kemiringan $23^{\circ}$. Kondisi daya PV yang semacam ini membuktikan bahwa PV yang dipasang dengan kemiringan tidak tepat dayanya akan menurun. Untuk mengetahui apakah PV sudah menghasilkan daya maksimal atau belum maka dengan pemodelan seperti pada paper ini dapat digunakan untuk mengevaluasi apakah PV yang dipasang sudah maksimal atau belum karena kesalahan pada posisi kemiringannya. Apabila PV dipsang secara permanen (statis), maka pemililihan kemirangan PV seharusnya tidak hanya diamati secara harian tetapi harus diamati selama satu tahun penuh agar didapatkan posisi kemiringan yang paling optimal selama PV 
tersebut dipasang. Perhitungan selama satu tahun ini diperlukan karena sudut deklinasi matahari selalu berubah setiap hari sepanjang tahun.

Untuk penurunan daya sebelum jam 08.40 dan sore hari setelah jam 14.00 bersifat simetris terhadap waktu tengah hari (noon time). Nila jam 08.40 dan 14.00 dapat berubah-ubah sesuai dengan sudut deklinasi matahari, sehingga batas waktu penurunan daya ( $\left.P_{\text {drop_time }}\right)$ ini dapat dirumuskan dengan persamaan berikut :

$$
P_{\text {drop_time }}=\text { Noon Time } \pm \frac{1}{15} \operatorname{acos}\left(\frac{-\sin (\varnothing)-\sin (x) * \cos (\varphi)}{\cos (x) * \cos (\varphi)}\right)
$$

Dimana $\varnothing$ merupakan sudut waktu efektif dengan nilai $30^{\circ}$ setelah matahri terbit atau $30^{\circ}$ sebelum matahari terbenam. Nilai $x$ merupakan formula pada equation time yang diperoleh dari persamaan 17. Sedangkan $\varphi$ merupakan posisi lintang secara geografis.

\section{KESIMPULAN}

Bedasarkan hasil pengukuran lapangan dapat dilihat prediksi daya untuk jam 08.40 sampai jam 14.00 memiliki akurasi yang tinggi terhadap hasil pengukuran $\mathrm{PV}$ dengan rata-rata error 4.72\%. Sedangkan untuk pagi hari sejak matahri terbit hingga jam 08.40 dengan rata-rata error sebesar $29.89 \%$. Pada sore hari sejak jam 14.00 sampai matahari terbenam memiliki selisih daya yang sangat besar dengan rata-rata error sebesar $15.40 \%$.

Kesalahan posisi kemiringan PV akan menyebakan penurun daya PV yang signifikan. Besar kecilnya penurunan daya karena kesalahan kemirigan PV nilainya akan selalu berubah-ubah sesuai dengan perubahan sudut deklinasi matahari yang selalu berubah setiap hari sepanjang tahun.

\section{DAFTAR PUSTAKA}

[1] Muhammed J. Adinoyi, Syed A.M. Said., "Effect of dust accumulation on the power outputs of solar photovoltaic modules", Elsevier, Renewable Energy 60 (2013), p. 633-636.

[2] H. Qasem, T.R. Betts, R. Gottschalg., "Spatially-resolved modelling of dust effect on cadmium telluride photovoltaic modules", Elsevier, Solar Energy 90 (2013), p. 154-163.

[3] Dzung D. Nguyen, Brad Lehman, Sagar Kamarthi, Solar Photovoltaic Array's Shadow Evaluation Using Neural Network with On-Site Measurement, IEEE Canada Electrical Power Conference (2007), p. 4449

[4] Yahia Baghzouz, Characteristics of $P V$ Power Systems. UNLV Las Vegas (2008).

[5] A. Bouilouta, A. Mellita, S.A. Kalogirou,. "New MPPT method for stand-alone photovoltaic systems operating under partially shaded conditions". Elsevier, Energy 55 (2013), p. 1172-1185.

[6] Lian Lian Jianga, Douglas L. Maskell, Jagdish C. Patrab,. "A novel ant colony optimization-based maximum power point tracking for photovoltaic systems under partially shaded conditions", Elsevier, Energy and Buildings 58 (2013), p. 227236.

[7] F. Brihmat, S. Mekhtoub, PV Cell Temperaturel PV Power Output Relationships Homer Methodology Calculation, IPCO(2014), vol 2.

[8] Matthew J. Reno, Clifford W. Hansen, Joshua S. Stein,. "Global Horizontal Irradiance Clear Sky Models: Implementation and Analysis". Sandia National lab, March 2012.

[9] R. G. Allen, "Task Committee on Standardization of Reference, The ASCE standardized reference evapotranspiration equation". Environmental, and E. Water Resources institute. Reston, Va.: American Society of Civil Engineers, 2005.

[10] Dzung D. Nguyen, Brad Lehman, Sagar Kamarthi,. "Solar Photovoltaic Array's Shadow Evaluation Using Neural Network with On-Site Measurement", IEEE Canada Electrical Power Conference, 2007.

[11] Ming Ding, Xinglong Wu,. "Three-phase Probabilistic Load Flow Including Photovoltaic Generation in Distribution System", International Journal of Automation and Power Engineering, 2012, p. 151-158.

[12] Rodolfo Araneo, Umberto Grasselli and Salvatore Celozzi,. "Assessment of a practical model to estimate the cell temperature of a photovoltaic module". 
International Journal of Energy and Environmental Engineering, 2014, 5:2

[13] Gueymard CA. The sun's total and spectral irradiance for solar energy applications and solar radiation models. Solar Energy 2004;76(4):423-53.

[14] Chen ZS, Mo SP, Hu P. Recent progress in thermodynamics of radiation-exergy of radiation: effective temperature of photon and entropy constant of photon. Science in China Series E: Technological Sciences 2008;51(8):1096-109.

[15] Virtuani A, Lotter E, Powalla M. Influence of the light source on the lowirradiance performance of $\mathrm{Cu}$ (In: $\mathrm{Ga}$ ) Se2 solar cells. Solar Energy Materials and Solar Cells 2006;90(14):2141-9.

[16] Pemanfaatan Energi Surya Di Indonesia, http://www.esdm.go.id/news-archives/56artikel/3347-pemanfaatan-energi-surya-diindonesia.html

[17] Kusdiana, Dadan., kondisi riil kebutuhan energi di indonesia dan sumber-sumber energi alternatif terbarukan, Direktorat Jenderal Listrik dan Pemanfaatan Energi Departemen Energi dan Sumber Daya Mineral, Bogor, 3 Desember 2008.

\section{Biodata Penulis}

Eka Prasetyono adalah dosen muda di Program Studi Teknik Elektro Industri Politeknik Elektronika Negeri Surabaya dengan bidang keahlian mikrokontroler dan otomasi industri.

Ragil Wigas Wicaksana adalah mahasiswa semester 8 di Program Studi Teknik Elektro industri Politeknik Elektronika Negeri Surabaya.

Novie A Windarko adalah dosen senior di Program Studi Teknik Elektro Industri Politeknik Elektronika Negeri Surabaya dengan bidang keahlian elektronika daya dan renewable energy.

Moh. Zaenal Efendi adalah dosen senior di Program Studi Teknik Elektro Industri Politeknik Elektronika Negeri Surabaya dengan bidang keahlian elektronika daya. 